\title{
Decarbonisation of Transport and Modal Split
}

\author{
Antonín Peltrám*, Josef Domácí \\ Institute of European integration- Banking College Prague \\ *Corresponding author: peltram@regard.cz
}

DOI: $10.2478 / \mathrm{v} 10158-010-0015-\mathrm{z}$

\begin{abstract}
A predominant section of world experts, policy-makers and the general public are concerned with the danger of climate change caused by great volumes of emissions which are potentially growing. These emissions are connected with the predicted growth of sectors of the economy with a high level of emissions (namely carbon dioxide). The European Union has organised a huge effort in science, research and development to decrease emissions based on the last frame programmes of R\&D\&I; joint technological initiatives with relevant sectors of the industry; legal groundwork, especially in road transport; incentives to markedly diminish the present $22 \%$ share of road transport in total emissions. It is clear that, despite some uncertainties due to the results of parallel research, and despite the development in progress not being known, e.g., what type of propulsion, based in principal on electric current from nuclear power stations being better (whether only network and batteries, or in addition hydrogen and fuel cells) should have the greatest energy or cost efficiency; the parallel effort assures incomparable benefits for future development. A great majority of the results of these activities should be usable even in other modes of transport, especially railways. The general description of expected results in the development of technologies have proved great expectations in changes in modal split in comparison with the recent position, with necessary changes in all future decades.
\end{abstract}

KEY WORDS: modal split, decarbonisation of transport.

\section{INTRODUCTION}

A significant section of global experts, policy-makers and the general public has been aware of the danger of climate change due to the great and continual growth of volumes of emissions of greenhouse gases, and has promoted an as large as possible reduction of the emissions (namely carbon dioxide). Such a target for the EU is very ambitious. Future development is contrary to the huge development of production, even in the sectors of the economy with the highest recent shares of emissions, which should be decreased during the next decades of the first half of this century to a level of the last decades of the last century.

Recently, the sector with one of the greatest shares of emissions is road transport, with nearly a 22\% share of total emissions. (Mentioned in all the main documents of the European Commission prepared both as a contribution of the EU for Copenhagen UN summit at the end of 2009, and discussions for the prepared White Paper on the European 
Transport policy 2020, and relevant parts of the documentation towards the programme Strategy Europe 2020 without any dispute).

Other deficiencies yet disputed are the non-renewability of sources of fossil fuels and the great share of these resources in politically or environmentally risky areas outside of Europe, and how to replace these with alternative sources whilst not reducing the efficiency to a significant extent. These are a series of topics solved within the $6^{\text {th }}$ and $7^{\text {th }}$ Frame programme of research and development.

Due to these main reasons there is an enormous effort by the European Union to reach the decreased level of emissions of greenhouse gases.

The basic tool is the immense activity in the area of science, research and development, massively supported through funding from the budget of the EU, with joint technological initiatives of the relevant production sectors of the industries, to combine this public funding with the private funding of the automotive industries and their suppliers, etc., with the maximum supporting legal and administrative measures and additional incentives for the private sector.

All these accepted proposals were based on a new generation of scientific and research projects. Therefore, in the References section we shall quote as literature only the basic documents of the European Commission as a superstructure providing innovations, instead of the many research papers and studies.

\section{SUBSECTOR ATTITUDE IN TRANSPORT}

It looks like the main attitude in the technological development of the European railways is the ERTMS system of control of railway traffic and proposals for investments to improve the quality of transport services. The competitive position of railways should by based on the lower emission of carbon dioxide and noise, but, because of similar future sources of energy and propulsion, these competitive advantages will be equalised. The idea is often expressed that local and regional railways, especially, will still have lasting subsidies in the year 2050, while the freight traffic could be without any subsidies by this time, because of the belief in more expensive fossil or alternative fuels and noise emissions. Due to renewed competiveness, the European railways should have, in the case of the transport market of goods, a dominant share of work for distances over $300 \mathrm{~km}$ and high-speed trains. There are no issues with propulsions, because of the high level of electric traction. However electrification of all modes of ground transport is supposed, and electrified local and regional lines should be additionally profitable to the railways magistral lines without trolley lines, based on the research intended now for road vehicles, if the density of traffic should not be too high to pay the expensive trolley line supply system.

Another repeated idea is to let road transport pay uncovered externalities. However, especially on regional and local rail lines, the main issue of comparability of externalities is in the density of the traffic: such a high number of transport railway units necessary to cover the cofounding (with public funds) costs of infrastructure, could only be reached on some parts of the network of local and regional railway lines in rural regions. On the other hand, the high density of road transport always needs only a fraction of the total cost of the road infrastructure per vehicle unit.

\section{OTHER FACTORS}

The development of the electrification of the transport system is only seldom connected with the anticipated nuclear fusion, instead of nuclear fissure, either through the business 
implementation of results of ITER (International Thermonuclear Experimental Reactor), or high-capacity lasers. The other priority of the implemented ITER is only a very small amount of nuclear waste; it is supposed that for a nuclear reaction and the production of electricity equivalent to 7 million coal equivalent there need be only 3.5 kilograms of plutonium, whereas the reaction should be in case of necessity stopped immediately.

In connection with such an energetic hope of mankind it is worth mentioning the tremendous change in the attitude to the discoveries in the nuclear sector: instead of competition combined with the highest degree of concealment, due to the primary military purpose of previous nuclear projects, there has been very close cooperation between the five competing industrial superpowers and the European Union, even though, only some decades ago, they were in the position of being the greatest military rivals. There was for a relatively long period hold-ups due to the competitive position of the site of the experimental facilities (either in Japan, or France- Cadarache, near Marseille, the effort of one half of the present participants of the ITER- Japan- after their bad 2nd world war experience with nuclear power; after European localisation, the locality was compensated by the position of Japan as a general director of the ITER, etc.). Other compensation has been in the sharing the additional joint world nuclear experimental facilities, supplementing, in some way, the main facilities. Successfully negotiated agreements caused great time delays in the starting stage of the project ITER.

\section{NEW PROPULSIONS AND TECHNOLOGIES INITIALLY SUPPOSED FOR ROAD VEHICLES}

The implementation of the ITER in the energy business would open the way to the massive electrification of road transport without some great present environmental constraints. Parallel to a relatively small part of conventional fuel with a very low prescribed level of emissions of carbon (through carbon dioxide), are alternative fuels for combustion engines, in next decades electrical propulsion using new batteries with accumulators with a higher capacity to bridge the distance between two power supply units or after daily operation to load the battery after some hundreds of kilometers of distance moved.

And despite disputes connected to issues with the storage and distribution of hydrogen, there is great hope for commercial hydrogen driven road vehicles, or of hybrid vehicles with basic drive using hydrogen and forced supplementary drive using the batteries of accumulators, with the recuperation of energy from breaking.

Hydrogen production demands cheap electrical energy. Nuclear fusion could give it.

Naturally, there are some above-mentioned issues concerning the storage and distribution of hydrogen for filling stations, due to the necessary safety measures for handling; much more risky than in the case of oil. But concerning research programmes this should be solved within the issues connected with the future energy policy.

All proposed changes should mean that if the recent number of motor vehicles is about 800 million, the predicated number of motor vehicles in 2030 could be 1600 million motor vehicles, and in 2050 about 2500 million; the recent level of emissions should drop by 2050 by $80 \%$ to $95 \%$. (About three documents - MEMO, Communication and supplementary information from 28th April 2020). This means that the present levels of emissions per car would drop on average to the level of only some $\%$ - mostly due to electrification. In the case of electromobils with the exception of abrasion of braking equipment and tyres, and the abrasion of carriageways, nearly all segments of emissions should mostly be reduced or disappear.

The most problematic issue with the rather limited possibility of improvements shall be in the case of the quality of the roads, because of money saved for decades necessary 
for the maintenance of and investments in the transport infrastructure and measures against floods.

There is another harmful effect: due to the periodic review of the Eurobarometer concerning road safety there are two main sources of road accidents, namely fatal accidents: the first is connected to the lack of discipline of drivers (hand-manipulated mobile phones included), the second due to the insufficient capacity and worse quality of road transport infrastructure.

\section{COST EFFICIENCY}

The new technologies of propulsions, namely electrification, are now about two to three times more costly than conventional propulsions. It is partially due to low-level (batch) production. Some issues could be solved using the legal practices of EU regulation -binding instructions to preferential buy the most energy- and emissions-efficient vehicles. As to the majority of cars used for commuting, especially in cities and towns (with more cars in household), the total costs could be even now reduced using smaller cars in comparison with present middle-sized vehicles.

There is huge support of the scientific activities, research and development of new types of batteries- with higher capacity and cheaper.

The decrease in the prices of electrical current for classical electric traction with trolley lines should be very significant, at least in comparison with fossil sources.

But there will be cheaper electrical current for the electrolysis of water to produce hydrogen for fuel cells, if they would be used.

Solving issues with the transportation of tanks with cheap liquid hydrogen could bring large impetus to the use of fuel cells, with rather simple equipment: two carbon electrodes with a small amount of catalyst, divided by a thin polymeric membrane that allows the protons to pass through. The hydrogen is then dissociated into protons and electrons on the catalyst layer. The protons pass through an external electric circle and essentially power the electric engine. Two protons are combined with two electrons and an atom of hydrogen from the air formed vapour of water and than hot water.

The prices of electrodes are rather high, as well as the polymeric membranes, but they have dropped even now very significantly on account of the research and development that has contributed to the considerable prolongation of service life.

The third element to the height of the price level and environmental friendliness is the above mentioned recuperation of $60 \%$ of energy during breaking.

There are some heavy disputes to the extent of the possible use of fuel cells in comparison with a "pure" electric car. The rather optimistic view could be caused by the practical application of this technology in buses. It could bring cheaper railway operation on account of unnecessary trolley lines.

But much lighter electric cars for cities are to be expected in comparison with present day vehicles of universal utilization, both for use in cities and for travelling long distances.

The total revolution in transport technologies could be illustrated by the fact that, just at present, there are emissions of noise and the noisy road transport are understood as an environmental constraint in comparison with railways (mostly because of housing closer to the road compared to railway infrastructure). But such hope will be false: the low level of noise emission of electric vehicles needs to produce an agreeable noise to warn other participants of road transport that an electric driven vehicle is coming.

During some future decades it is possible to suppose that due to the decreased prices of road vehicles and their operation, and because of the higher standards of living, everyone 
with prescribed age and healthy conditions could have and drive motor vehicles, and may be prolonged by means of ICT, if he would decide to have it.

On one hand there is a good perspective of the possibility to reach rather comparative prices of new transport technology with the conventional. On the other hand, as it was mentioned, the new types of propulsions based on electricity have not been developed only for road transport.

\section{THE MAIN FUTURE CONSTRAINTS}

In case of road transport there should be only two groups of constraints in the future:

- The capacity of transport infrastructure for traffic operation on roads and in streets for through traffic, because issues of created obstacles by parked cars for through traffic not only make smooth traffic flow difficult, but block emergency traffic too. The issue shall be, in comparison with today, much more difficult, not only because of the growth in the number of cars, but also the traffic of goods, choosing road transport: in the period 2000- June 2008 July 2008 (which has been announced as the starting point of the financial/economic crisis) the rates of growth of employment of small and medium size enterprises (SMEPs) were, in the European Union, $1.9 \%$ per year on average, in comparison with large enterprises with only $0.5 \%$. It is supposed that after the crisis this relation in the growth of enterprises should continue, if it shall happen to implement all 10 groups of issues supposed by the Act of small enterprises. But despite this precondition only $20 \%$ of SMEPs are involved in cross- board operations. Their share of turnover on cross-border operations has been only $8 \%$. It means that the predominant markets are on local and regional levels, with the requirements of a lesser amount but higher frequency of orders. The requirements will therefore incline to traffic on a local and regional level, and this means to road transport.

- A part of these expected future bottlenecks could be reduced, especially in daily commuter traffic.

- But in general all cuts in road investments cannot be caught up, with tremendous effects on the smoothness of traffic and, in parallel, on a higher rate of accidents, including fatal incidences.

- The second case of issues is to build enough capacity for parking and put aside vehicles, not used for daily traffic, but for example only during weekends.

- There is no alternative, especially not for parking in streets, because they will block through traffic.

\section{INTEGRATED TRANSPORT SYSTEMS}

As to the above-mentioned remarks, the only possibility is to decrease daily traffic and in such a way to slightly diminish great future bottlenecks.

To find the best modal split under the future conditions it is necessary

- to revaluate the old-fashioned hypothesis that a vehicle with higher capacity is ceteris paribus more efficient, despite the level of insufficiently used occupation, because the excessive offered capacity would be used later on. 
- then, based on the environmental parameters of new vehicles (mainly the substantial amount of emissions of carbon dioxide), to derive a lower and upper limit of occupation of vehicles in order to find the optimal solution of the relation capacity- consumption of fuel- emission- acceptable costs.

- $\quad$ it is necessary to clarify the prolonged travel time (travel distance) for combined transport (journeys with a necessary change of means of transport), that in any way should lengthen the travel time without change.

- sub-alternative is the change of vehicles in points (junctions) with consolidation of flow of passengers of vehicles with low capacity and consumption, with a change for vehicles with higher capacity and its adequate use and therefore lower specific consumption.

- if possible to compensate time delays by higher comfort of travelling and/or prices of tickets.

- could be possible to connect breaks in travel time by changing the vehicles providing supplementary services for passengers?

- $\quad$ permanently or

- $\quad$ only during some journeys depending on daily hours, days in week?

- because the decisive element should be the choice of the passengers.

- integrated transport systems due to more participating operators need excellent control and information systems of participating vehicles, drivers, passengers, not only for smooth normal traffic operations, but especially in the case of any interruption of transport operations of any participant of the system, with the necessary costs that could be compared not only with lower consumption, lower amount of emissions, but also cost efficiency.

\section{CONCLUSIONS}

In principle it is necessary to say that the future optimal modal split could neither be based on the previous paradigms nor on paradigms valid for the whole period from recent to future time horizons 2020, 2030, 2050. The pace of the development of society and technology is too quick.

Technological development could further satisfy the needs of mobility using cars with an acceptable environmental impact, or transport means of collective transport within the framework of integrated passenger transport systems, influenced partially in the case of short distance travelling by the excellence of the organisation of transport with only very short and acceptable interruptions of journeys connected with changing the means of transport. Integrated transport systems could spare segments of the capacity of the infrastructure with a greater occupancy of vehicles of collective transport, if it should happen to necessarily reach at least lower occupation, with prices and comfort comparable with cars.

The only threat to the smooth flow of traffic and the rate of accidents inclusive with fatal consequences will be the insufficient level of quantity and quality of road transport infrastructure in general, even in the case of roads and streets of lower classes.

The development of high-tech in the case of vehicles of all modes of transport and the growing level of safety measures should not be a great contradiction to the level 
of infrastructure, even after reaching the level of minimal harmful environmental impact, otherwise there should be great problems and even danger to life.

But the many decades of time delays in financing transport infrastructure, combined with the relatively high degree of road accident frequencies fatal accidents included in connection with some delays caused by present financial / economic crisis could sharpen such imbalances.

\section{REFERENCES}

SONERAIL- Project within the framework of $4^{\text {th }}$ Frame Programme- Transport, 1997-1998.

Bickel P.- Friedrich R.: Externalities of energy. Methodology 2005, updated European Commission.

INFRA;CE Delft; Fraenhofer Geselschaft- ISL University of Gdansk: Handbook of Estimation of External Costs in the Transport Sector. Delft 2008.

The European Commission working document: Consultation on the future "EU 2020" Strategy. Com(2009).

Studies of the Institute of European Integration of Banking College concerning environmental and economic losses caused by postponed construction of Prague Circle 2007,2008.

Doprava a životní prostředí. Institute of European Integration, Banking College Prague 2009, Publishing House Nadatur, Prague 2009.

Proposal of the Directive of the European Parliament and Council (support for clean and energy efficient road vehicles (Směrnice Evropského parlamentu a Rady o podpoře čistých a energeticky účinných silničních vozidel- LEX 998/2009).

Announcement of take effect of this Directive from the $3^{\text {rd }}$ of December 2010.

Communication from the Commission: EUROPE 2020. A strategy for smart, sustainable and inclusive growth. $\mathrm{COM}(2010) 2020.3 .3 .2010$.

Clean and energy-efficient vehicles- European strategy for the uptake of green vehicles. MEMO/10/153 $28^{\text {th }}$ April .2010.

Regulation of the European Parliament and Council from 22.9. 2010 to the European strategy for railway network for competitive transport of goods.

Study on Regulatory Options Further Market Opening in Rail Passenger Transport. EverisNTU Final report 09.09.2010.

Documentation to the proposal of European transport policy 2011-2020/namely speech of vice-president of the European commission responsible for transport Siim Kallas, Hamburg transport fairs 17. 9. 2010.

European Commission: programme Strategy Europe 2020. July 2010. 
Seminars of the Joint technological platform of road transport and ERTRAC (European Road Transport Research Advisory Council.

Communication of the European Commission to the European Parliament, Council and Economic and Social Committee from the 28.4.2010 An European Strategy on clean and energy efficient vehicles (COM 2010/186.

Leaflet „TriHyBus. 21th century city transport. 2010“, Prague 2010. 